\title{
Implementation of Notary House Employment Agreements in the Selling of Land and Building
}

\author{
Indra Muliawan ${ }^{*}$ and Jawade Hafidz ${ }^{* *}$ \\ *) Faculty of Law, Universitas Islam Sultan Agung (UNISSULA) Semarang, E-mail: \\ indramuliawan23596@gmail.com \\ ${ }^{* *}$ Faculty of Law, Universitas Islam Sultan Agung (UNISSULA) Semarang, E-mail: \\ jawade@unissula.ac.id
}

\begin{abstract}
The research entitled "Implementation of Notary House Vacationing Agreements in the Sale and Purchase of Land and Buildings in Randudongkal Pemalang Regency", in order to find out and analyze the legal protection of buyers in the implementation of notarial house emptying agreements in the sale and purchase of land and buildings, as well as obstacles and solutions to realize a sense of belonging justice for the implementation of the notarial vacancy agreement in the sale and purchase of land and buildings. This study uses an empirical juridical approach, which is a legal research conducted by researching and examining existing facts in line with observations in the field. Legal protection against the buyer in the implementation of the notarial house emptying agreement in the sale and purchase of land and buildings, is considered This is important because the sale and purchase agreement has been signed so that the object of sale and purchase has turned into the property of the buyer, however the seller or other person who occupies the house has not been able to leave or vacate the house. The seller or other person who occupies the house cannot immediately vacate the house after the rights have been transferred, because they are not ready to move house or have not obtained a replacement house. Based on these circumstances, the parties agree to make a separate agreement to complete the sale and purchase agreement that has been made. The agreement is agreed upon by the seller and the buyer or the parties in the form of an agreement to vacate the house which is notarized. Legal certainty of a notarial vacancy agreement, concerning when the seller or other person who occupies the house leaves or vacates the house. If the specified date turns out to be that the seller or other person occupying the house cannot leave or vacate the house, a fine per day is imposed, the amount of which is agreed upon in the agreement by the seller and buyer or the parties. In the notarial agreement to vacate the house, it is necessary to include a clause that the buyer is obliged to provide severance pay to the seller as much as agreed by both parties. Severance pay must be paid by the buyer to the seller after the house is delivered empty by the seller to the buyer. This is intended as compensation that has been agreed between the seller and the buyer, and as a balance between the rights and obligations obtained by both parties in the agreement. If the seller or other
\end{abstract}


person occupying the house is ready to leave or vacate the house, but the buyer is unable to pay or provide severance pay to the seller or other person who occupies the house, the buyer is subject to a fine as much as agreed by the parties.

Keywords: Certainty; Protection; Sale; Purchase; Agreement.

\section{Introduction}

The house is a basic human need for shelter, which is an important factor in increasing the dignity of life and human welfare, which in essence is part of full human development, in accordance with the national development goals, namely a just and prosperous society based on Pancasila and the Constitution. 1945.

Article 1 paragraph (3) of the 1945 Constitution affirms that the State of Indonesia is a state of law, implies that all life structures of the nation, society and state are based on law. The statement of the rule of law was then marked by the existence of a judicial institution tasked with enforcing the rule of law. ${ }^{1}$

The need for housing for housing is basically directly proportional to the increase in population. The need for a house for residential purposes cannot be separated from land, because land, apart from the place where the house is built, is also an important element that cannot be separated in human life.

According to the provisions of Article 1 point 7 of Act No. 1 of 2011 concerning Housing and Settlement Areas, it is a building that functions as a suitable place to live, a means of fostering a family, a reflection of the dignity and worth of its inhabitants, as well as an asset for its owner. Meanwhile, according to the World Health Organization (WHO), the house is a physical structure or building for shelter, where the environment is useful for physical and spiritual health and social conditions both for the health of families and individuals.

One of the transfer of ownership rights to a land can be done by buying and selling. Based on Article 37 paragraph (1) of Government Regulation Number 24 of 1997 concerning Land Registration, it can be seen that for the transfer of land rights an authentic deed is required which is made by a public official called the Land Deed Making Officer (PPAT) who is appointed by the government.

The process of transferring ownership of land other than through a sale and purchase agreement, can also be due to the distribution of joint rights, grants, and inheritance. Meanwhile, in the transfer of land rights due to sale and purchase, payment must be made in cash. If the payment is not made in cash, then a sale and purchase agreement cannot be made before the Land Deed Making Officer (PPAT).

\footnotetext{
${ }^{1}$ Article 1 paragraph (3) of the Constitution 1945
} 
Before the sale and purchase is made before the Land Deed Making Officer (PPAT) for the process of transferring rights, the parties must collect and submit the requirements in accordance with the agreement to be made and what the Land Deed Making Official (PPAT) needs in making the deed. The data of the parties concerned include the original certificate or letter $C$ (if you do not have a certificate), a photocopy of an electronic Identity Card (KTP), a photocopy of a Family Card (KK), and a photocopy of the Marriage Book (provided that you have shown the original documents in front of you). Land Certificate Making Official or called PPAT), Death Certificate issued by the local Village or Death Certificate issued by the local Population and Civil Registry Office (if any party has died), Before the transfer of land rights, checking the certificate at the local Land Office is the first step that must be carried out by the Land Deed Making Official (PPAT). Then the Land Value Zone (ZNT) is registered to find out the value of the land in the area where the land is located.

In order for each plot of land to have definite legal force, land registration must be carried out at the local Land Office. According to Article 1 point 1 of Government Regulation Number 24 of 1997, what is meant by land registration is a series of activities carried out by the Government continuously, continuously and regularly, including collection, processing, bookkeeping and presentation and maintenance of physical data and juridical data in the form of maps and lists of land parcels and apartment units including the provision of proof of rights called certificates, for parcels of land that already have rights and ownership rights to flat units, as well as certain rights that encumber them . $^{2}$

According to Article 1 point 6 of Government Regulation Number 24 of 1997, Physical Data is information regarding the location, boundaries and area of land parcels and apartment units registered, including information regarding the existence of buildings or parts of buildings above them.

According to article 1 point 7 of Government Regulation Number 24 of 1997, Juridical Data is information regarding the legal status of registered land parcels and flats, their rights holders and the rights of other parties as well as other burdens that burden them.

According to Article 3 of Government Regulation Number 24 of 1997, the objectives of land registration are:

1) To provide legal certainty and legal protection to holders of rights to a land, apartment units and other registered rights so that they can easily prove themselves as holders of the rights concerned;

2) To provide information to interested parties including the Government so that they can easily obtain the data needed to carry out legal actions regarding registered land parcels and apartment units;

\footnotetext{
2 Widyarini, Indriasti Wardani et al, 2018, Hukum Pertanahan, Semarang, Faculty of Law, University of 17 August 1945 (UNTAG) Semarang.
} 
3) For the implementation of orderly land administration.

According to Article 9 paragraph (1) of Government Regulation Number 24 of 1997, the objects of land registration include:

1) Plots of land owned with Ownership Rights, Cultivation Rights, Building Use Rights, and Use Rights;

2) Management Land Rights;

3) Waqf Land;

4) Flat Ownership Unit;

5) Mortgage right;

6) State Land.

For carry out definite land registration, data collection must be carried out for the requirements needed in the process of transferring rights. In the process, several stages are carried out before the transfer of rights is registered at the local Land Office, one of the requirements needed is the existence of a deed made before the Land Deed Making Officer (PPAT) where the land is located.

In the midst of people's lives in the transition of land rights due to buying and selling, if a house is built on it, the buyer sometimes cannot immediately occupy it even though it has been paid in full, because the seller has not been able to hand over the house in an empty condition to the buyer. So that the seller can immediately vacate and hand over the house being sold to the buyer, another agreement is made to complete the sale and purchase agreement or the transfer of rights, namely an agreement to vacate the house in a notarial way. The agreement is made notarial in order to provide certainty and legal protection to the buyer ${ }^{3}$.

The subject of discussion here is the implementation of the notarial vacancy agreement, which is made to complete the sale and purchase agreement of the land on which the house is built. The object of land in question is in the form of land rights, because the object of land can be in the form of land rights or state land. Thus, the house building is attached to the land being sold, or it can happen that only the house building becomes the object of sale and purchase if it is standing on state land.

The problem in the sale and purchase agreement of the land on which the house is built, if the seller or other person who occupies the house has not been able to leave or leave the house, after the sale and purchase agreement is signed. The seller or other person who occupies the house cannot immediately vacate the house after the rights have been transferred, because they are not ready to move house or have not obtained a replacement house. Based on these

${ }^{3}$ Deen, Thaufiq., Ong Argo Victoria \& Sumain. (2018). Public Notary Services In Malaysia. JURNAL AKTA: Vol. 5, No. 4, 1017-1026. Retrieved from http://jurnal.unissula.ac.id/index.php/akta/article/view/4135 
circumstances, the parties agree to make a separate agreement to complete the sale and purchase agreement that has been made. The agreement is agreed upon by the seller and the buyer or the parties in the form of an agreement to vacate the house which is notarized.

The notarial agreement to vacate the house is based on and reflects the characteristics of the agreement regulated in Article 1338 paragraph (1) of the Civil Code, that all agreements made legally apply as law for the parties who make thempacta sun servanda). This is intended because with the consensus of the parties in the contract, the power to bind the contract arises as befits the law. What a person declares in a legal relationship ${ }^{4}$ becomes law for them (cum nexus faciet mancipiumque, uti lingua mancouassit, ita jus esto). This principle becomes the binding force for the contract (verbindende kracht van de overereenkomst). This is not only a moral obligation, but a legal obligation whose implementation must be obeyed. As a consequence, neither judges nor third parties may interfere with the contents of the agreement. ${ }^{5}$

Matters that need to be considered and included in the notarial vacancy agreement are $^{6}$ :

1) When can the seller or the owner of the house leave the house he is selling and hand over the keys to the house he is selling

2) If the specified date turns out to be that the seller or the occupant cannot leave the house he is selling to the buyer, a fine per day is imposed, the amount of which is agreed upon by the parties, namely between the seller and the buyer.

3) What if the buyer is unable to pay or provide severance pay to the occupant, even though the seller or the occupant is ready to vacate the house.

4) Penalties to buyers if they do not pay severance pay.

\footnotetext{
${ }^{4}$ Farhati, Dewi \& Akhmad Khisni. (2018). Legal Review Of Implementation Endowments Authority Relating To The Under Hand Agreement Made By Waqif (Case Study In Kua Wonosalam, Demak). JURNAL AKTA: Vol. 5, No. 3. Retrieved from http://jurnal.unissula.ac.id/index.php/akta/article/view/3256/2392

${ }^{5}$ Ridwan Khairandy, Kebebasan Berkontrak \& Pacta Sunt Servanda Versus Iktikad Baik:Sikap Yang Harus Diambil Pengadilan, FH UII Press, p. 38.

${ }^{6}$ Rachmawati, Noor., \& Hanim, Lathifah. (2018). Notary Role in The Establishment of Foreign Investment Limited Company Based on The Act No. 25 Of 2007 on Investment in Semarang. JURNAL AKTA: Vol. 5, No. 4, 965-974. Retrieved from http://jurnal.unissula.ac.id/index.php/akta/article/view/3939
} 
In the notarial agreement to vacate the house, it is agreed to include fines. ${ }^{7}$ This is intended to make the agreement effective as desired by the parties, namely the seller and the buyer, so that there is legal certainty.

In addition to the agreement of the parties, the agreement to vacate the house in a notarial manner must meet the legal requirements of an agreement as contained in Article 1320 of the Civil Code:

1) Agree on those who bind themselves;

2) The ability to make an engagement;

3) A certain thing;

4) A lawful reason.

In the implementation of the agreement to vacate the house, problems can arise which are deviations from the agreement that has been made and agreed upon by the parties. Because the problems in the agreement are interesting to explore more deeply regarding the problems and solutions. With the possibility of problems arising from deviations from the terms agreed upon by the parties in the notarial vacancy agreement ${ }^{8}$.

\section{Research Methods}

The approach method in this study is an empirical juridical research method. Empirical juridical research is legal research regarding the enforcement or implementation of normative legal provisions in action on every particular legal event that occurs in society, namely studying and researching Law in Action. ${ }^{9}$ The juridical approach is an approach that emphasizes in terms of legal norms that exist in laws and regulations, and other legal provisions. The approach in this research is to provide an analysis in the field of the implementation of notarial house emptying agreements in the sale and purchase of land and buildings in Randudongkal, Pemalang Regency ${ }^{10}$.

\footnotetext{
${ }^{7}$ Interview with Dwi Murti Setyowati, SH, Notary and PPAT Pemalang Regency In Randudongkal, 7 July 2020.

${ }^{8}$ Sukarmi \& Ong Argo Victoria. (2018). Cash Waqf in Sustaining Of Indonesian Society "In Legal \& Economic Perspective". AL-ITQAN: Journal of Islamic Sciences: IIUM Malaysia. https://journals.iium.edu.my/al-itqan/index.php/al-itqan/article/view/43

${ }_{9}^{9}$ Abdulkadir Muhammad, Hukum \& Penelitian Hukum, (Bandung : Citra Aditya Bakti, Bandung,2004), p. 134.

${ }^{10}$ Widyawati, \& Handoko, Widhi. (2018). The Notary Role / PPAT in Improving Legal Awareness Society to Perform Registration Rights to Land Based on Government Regulation No. 24 of 1997 on Land Registration. JURNAL AKTA: Vol. 5, No. 4, 975-980. Retrieved from http://jurnal.unissula.ac.id/index.php/akta/article/view/4127
} 


\section{Results and Discussion}

\subsection{Buyer's Legal Protection in Notarial Employment Agreements in the Sale and Purchase of Land and Buildings}

Legal protection is the protection of the dignity and worth, as well as the recognition of human rights owned by legal subjects based on legal provisions from arbitrariness or as a collection of rules or rules that will be able to protect one thing from another. ${ }^{11}$ To provide legal protection as a description of the workings of the legal function to realize the purpose of the law itself which consists of justice, certainty, and the benefit of the law.

Protection Law is a protection given to legal subjects in accordance with the rule of law, whether it is preventive (prevention) or in a repressive (coercive) form, both written and unwritten in the context of enforcing legal regulations.

Emptying house is forcing or ordering someone who occupies someone's house to leave the house they are occupying because they no longer have rights to the house in question. So that the person who is entitled to the house in question can be forcibly asked for assistance from the authorities/police to vacate the house in question. ${ }^{12}$

Agreement Emptying the house is an agreement made to anticipate that someone who occupies a house that is no longer his right to leave or move from a house that is no longer his right or when the owner of the house no longer has rights to the house he occupies.

So the party who occupies the house there are 2 (two) possibilities, namely:

1) The occupant is the owner of the house.

2) The occupants are not the owner of the house there are 2:

a. The occupants are the tenants of the house.

b. Those who occupy the house still have family relations. ${ }^{13}$

To obtain legal certainty and protection in the vacating of the house, the seller and the buyer or the parties will make a notarial agreement to vacate the house before a notary. In the Notary Deed, rights and obligations will be formulated based on the agreement of the parties. All of that as long as the making of the Deed is not assigned or excluded to other officials or other people stipulated by law. Meanwhile, Article 1 point 7 in the Law above explains that a Notary Deed,

\footnotetext{
11 Philipus M. Hadjon, 2011. "General Theory of Law and State", diterjemahkan oleh Rasisul Muttaqien, Bandung, Nusa Media, p. 25.

${ }^{12}$ Interview with Dwi Murti Setyowati, SH, loc. cit.

13 Ibid.
} 
hereinafter referred to as a Deed, is an authentic deed made by or before a Notary according to the form and procedure stipulated in this Law.

According to Article 1 point 1 of the Government Regulation of the Republic of Indonesia Number 37 of 1998 concerning Position Regulations for Land Deed Making Officials, what is meant by Land Deed Making Officials, hereinafter referred to as PPATs are public officials who are authorized to make authentic deeds regarding certain legal actions regarding rights on land or Ownership Right to Flat Unit juncto Article 1 point 4 which is meant by PPAT Deed is a deed made by PPAT as evidence that certain legal actions have been carried out regarding land rights or Ownership Rights to Flat Units.

Thus, the making of the Sale and Purchase Deed which is carried out before the Land Deed Making Officer (PPAT) is the basis for making a Notarial Deed of Employment Agreement before a Notary That the basis for the agreement to vacate the house is made by the seller and the buyer or the parties because the house that stands on the land which is the object of the sale and purchase is still occupied by the seller or another person, even though the sale and purchase has been carried out in cash and ownership rights have been transferred to the buyer.

As stipulated in Article 1313 of the Civil Code which defines an agreement as follows:

"Agreement is an act by which one or more persons bind themselves to one or more other persons". The occurrence of binding oneself to one or more other people has legal consequences, namely the emergence of rights and obligations for each party who binds themselves. The obligation in this case is in the form of fulfilling an achievement from one or more parties to one or more other parties who are entitled to such an achievement.

So it can be concluded that an agreement always has 2 (two) or more parties, that one party is obliged to carry out an achievement (called the debtor), while the other party is the party entitled to receive an achievement (called the creditor).14 Similarly, in a sale and purchase agreement, 2 (two) parties must bind themselves together, which is referred to as the seller and the buyer.

As explained in Article 1457 of the Civil Code concerning buying and selling that:

"an agreement whereby one party binds himself to surrender an object, and the other party pays the agreed price". The formulation above explains that in buying and selling, it gives birth to reciprocal obligations to the parties who make the sale and purchase agreement. ${ }^{15}$

The formulation of a sale and purchase agreement must be carried out in good faith considering that buying and selling is an agreement to bind himself to hand

\footnotetext{
14 Kartini Muljadi \& Gunawan Widjaja, Perikatan Yang Lahir dari Perjanjian, (Jakarta: Raja Grafindo Persada, 2008, p. 92.

${ }^{15}$ Gunawan Widjaja \& Kartini Muljadi, Jual Beli, (Jakarta: PT Raja Grafindo Persada, 2003), p. 27.
} 
over an object to another party. Thus the principle of good faith is very important to avoid hidden defects in objects being traded. ${ }^{16}$

Based on the article above, it is the obligation of the seller to safely guarantee the goods he wants to sell from harmful disturbances. The seller must also explain important things that must be known by the buyer so that when a dispute occurs over the object of sale and purchase it does not cause harm to the buyer. It is not only the seller who must have good intentions when selling an item, on the other hand, the buyer is also obliged to have good faith by examining the condition of the item from hidden defects before buying an item. As explained in Article 1338 of the Civil Code paragraph 3, that an agreement made must be based on good faith from both parties, which means that every act and implementation of a sale and purchase agreement based on good faith must heed the substance of the agreement on the basis of trust between the two parties. However, if in the making or implementation of the agreement, bad faith is found by one of the parties, then the party with good intentions will receive legal protection. ${ }^{17}$

In connection with the agreement that has occurred in the sale and purchase, that the agreement must be given freely. There are 3 (three) things in contract law that cause an agreement not to contain freedom, namely: ${ }^{18}$

1) there is coercion;

2) mistake or error; and

3) fraud.

Coercion in this case is in the form of spiritual coercion or mental coercion (psychic), not in the form of physical (physical) coercion which emphasizes the threat of an act that is prohibited. ${ }^{19}$ For example, the seller must sign a deed of sale and purchase as a form of agreement because of a life threat carried out by another party so that he is forced to agree to the sale and purchase. Errors or mistakes occur when one of the parties errs regarding the main points of what has been agreed, also related to the important properties of the object that has been agreed, or also related to whom the object of the sale and purchase will be handed over. ${ }^{20}$ For example, the buyer experiences an error because before making the sale and purchase transaction he does not first examine the condition of the object (land) on which the building stands from hidden defects.

\footnotetext{
${ }^{16}$ Ridwan Khairandy, Itikad Baik dalam Kebebasan Berkontrak, (Jakarta: Fakultas Hukum Universitas Indonesia, 2003), p. 217.

${ }^{17}$ Yunirman Rijan and Ira Koesoemawati, Cara Mudah Membuat Surat Perjanjian/Kontrak \& Surat Penting Lainnya, (Jakarta: Raih Asa sukses, 2009), p. 8.

${ }^{18}$ Subekti, Hukum Perjanjian, (Jakarta : Intermasa, 2008), p. 23, 24.

${ }^{19}$ Ibid., p. 22.

${ }^{20}$ Ibid., p. 23.
} 
Furthermore, fraud can occur, when one party intentionally provides false information that is not in accordance with the facts regarding the object to be traded, accompanied by a ruse to persuade the buyer so that the buyer wants to buy the object (goods).

It can also be categorized as fraud because it occurs when one party actively influences the other party by providing false information that is in accordance with the facts accompanied by deception.21Thus the manufacture or implementation of the agreement found bad faith by the seller, then the party with good intentions, namely the buyer, must get legal protection.

As explained in the description above, that legal protection can be divided into preventive legal protection and repressive legal protection. Preventive legal protection is provided based on statutory regulations. Legal protection for buyers with good intentions can be found in several articles of legislation because they clearly contain elements of error and fraud. Article 1491 of the Civil Code provides protection in the form of guarantees which state that: "The insurance that is the obligation of the seller to the buyer is to guarantee two things, namely the first control of the object being sold in a safe and secure manner; second to the existence of hidden defects in the goods, or in such a way as to issue reasons for canceling the purchase."

The insurance, although not agreed upon at the beginning of the making of the sale and purchase agreement, is still valid and binding on the seller as stated in Article 1492 of the Civil Code, namely:

Even though at the time the sale was made there was no promise of guarantee, but the seller is by law obliged to bear the buyer against a penalty for surrendering all or part of the object sold to a third party, or for expenses which according to a third party's information he has the object and which was not notified when the purchase was made."

Based on Article 1491 of the Civil Code, the seller in carrying out buying and selling transactions must first guarantee that the control of the object is safe without any interference from any party, and explain important things related to the object from hidden defects, this is included in preventive protection.

Furthermore, repressive legal protection is protection given when a violation of the law has occurred. The form of protection is in the form of law enforcement which includes the provision of sanctions. For buyers who have good intentions or one of the parties does not meet the performance as agreed, they can get compensation according to the provisions of Article 1267 of the Civil Code, that: "The party to whom the agreement is not fulfilled, can choose whether he, if it can still be done, will force the other party to fulfill the agreement, or he will demand the cancellation of the agreement, accompanied by reimbursement of costs, losses and interest."

${ }^{21}$ Ahmadi Miru, Hukum Kontrak Perancangan Kontrak, (Jakarta: Raja Grafindo Persada, 2007), p. 5. 
Binding themselves to each other between the seller and the buyer will cause legal consequences, namely the existence of an obligation in this case in the form of fulfilling an achievement from the seller to deliver the object (object) which is the object of sale and purchase to the buyer. The buyer is also obliged to pay for the object he has purchased in accordance with the agreement with the seller.

The sale and purchase agreement is not only in the form of a sale and purchase agreement between the two parties, but also must pay attention to the legal terms of an agreement so that there is no agreement that is null and void or can be canceled.

An agreement must meet the conditions for a valid agreement, as explained in Article 1320 of the Civil Code, that there are 4 (four) kinds of conditions for a valid agreement, namely:

1) Agree on those who bind themselves;

Agree means that the subject who enters into the agreement must agree, agree on the main points of the agreement that is entered into. What one party wants is also desired by the other party, so they want something reciprocally.

2) The ability of the parties to make an agreement;

The person entering into the agreement must be competent according to law. In principle, everyone who is mature and in sound mind is capable according to the law. According to Article 1320 of the Civil Code, what is meant by legal competence are those who are 21 years old or not yet 21 years old but have been married or have been married.

3) A certain thing;

A certain thing means that the type or type of object or goods in the agreement has been determined. Regarding the goods that already exist or are in the hands of the interested party at the time the agreement is made, it is not required by law and also the amount does not need to be stated.

4) A lawful cause or cause;

What is meant by a lawful cause is the content of the agreement itself. Because what is not lawful is contrary to the law, decency, public order. As regulated in Article 1337 of the Civil Code, that a cause is prohibited, if it is prohibited by law, or if it is contrary to good decency or public order.

The conditions mentioned above are related to the subject and object that must be in the agreement. The first and second terms are related to the subject of the 
agreement (subjective terms). Subjective requirements are for the agreement and the skills of the parties who make the agreement have met these requirements. While the third and fourth conditions are related to the object of the agreement (objective requirements). The objective requirement is a certain subject matter and a cause that is not prohibited in buying and selling. If one of the four elements is not fulfilled, it will cause the defect of an agreement. An agreement does not meet the subjective requirements, then the agreement can be canceled or as long as the agreement has not been or has not been canceled by the court, the agreement is still valid. Furthermore, if an agreement does not meet the objective requirements,

The purpose and objective of the agreement to vacate the house made before a Notary is to guarantee legal protection, especially to the buyer, because the buyer already owns the object of land and house based on the sale and purchase agreement made between the seller and the buyer before the Notary as the Land Deed Maker Official (PPAT). The sale and purchase agreement between the seller and the buyer is the basis for the agreement to vacate the house. Therefore, the agreement to vacate the house cannot be made stand-alone, but there must be another agreement as the basis for making the agreement, including a sale and purchase agreement.

In practice in the community, sometimes the buyer cannot immediately occupy the purchased house even though it has been paid in cash, because the seller cannot immediately leave or vacate the house even though the sale and purchase has been carried out in cash. Therefore, it is necessary to make a notarial agreement to vacate the house before a notary to protect the rights and interests of the buyer.

The notarial agreement to vacate the house cannot stand alone and cannot be separated from the previous (previous) agreement, namely the sale and purchase agreement, because the parties to the agreement are the same subject as well as the object. So the legal protection of the buyer in the notarial vacancy agreement must also be applied the same as the legal protection in the sale and purchase agreement.

The buyer's legal protection in the notarial vacancy agreement in the sale and purchase of land and buildings, is intended to protect the rights and interests of the buyer against the object of sale and purchase in the form of the land on which the house is built, because the object is still occupied by the seller or another person even though it is legally owned. Protection of the buyer is stated in the agreement made between the seller and the buyer, namely the notarial emptying of the house before a notary. In order to bind the seller and the buyer, the agreement in addition to an agreement between the seller and the buyer must also fulfill the conditions for the validity of the agreement.

The notarial agreement to vacate the house is based on and reflects the characteristics of the agreement regulated in Article 1338 paragraph (1) of the Civil Code, that all agreements made legally apply as law for those who make 
them (pacta sun servanda). This is intended because with the consensus of the parties in the contract, the power to bind the contract arises as befits the law. What a person declares in a legal relationship becomes law for them (cum nexus faciet mancipiumque, uti lingua mancouassit, ita jus esto). This principle becomes the binding force for the contract (verbindende kracht van de overereenkomst). This is not only a moral obligation, but a legal obligation whose implementation must be obeyed. As a consequence, neither judges nor third parties may interfere with the contents of the agreement. ${ }^{22}$

In addition to being based on the provisions of Article 1338 paragraph (1) of the Civil Code, a notarial house emptying agreement as a sale and purchase agreement must also meet the four legal requirements of an agreement regulated in Article 1320 of the Civil Code, namely agreeing those who bind themselves, the ability to make an agreement, a matter certain, a lawful cause.

The notarial agreement to vacate the house is made because in the sale and purchase agreement made before the Land Deed Making Officer (PPAT) the homeowner has not been able to hand over the empty house to the buyer, while the buyer has paid in full. In addition, so that the buyer's rights are fulfilled and get legal protection because he has paid in full to the seller, and so that the seller immediately submits or vacates the house to the buyer on time as agreed and agreed between the parties.

Furthermore, in order for the seller to leave or vacate the house on time, the seller by the buyer is given severance pay, the amount of which depends on the agreement between the seller and the buyer. So that when the seller hands over the keys and the house is empty to the buyer, the seller will receive the money as agreed between the seller and the buyer in the deed of emptying the house.

If the seller is late in handing over the house to the buyer, a time limit is specified in the agreement, and if it exceeds the agreed time limit, the seller will be subject to a fine with a time limit as well. The fine is as much as agreed between the seller and the buyer. If the seller has passed the time limit for the fine that has been agreed with the buyer, the buyer can forcibly vacate the house with the help of the authorities/police.

On the other hand, the seller is ready to hand over the keys and an empty house to the buyer but the buyer is not ready to give severance pay to the seller, so the buyer is also subject to a fine, the amount of which is determined based on an agreement between the seller and the buyer indefinitely. However, the sale and purchase agreement made before the Land Deed Making Officer (PPAT) as the basis for the notarial agreement to vacate the house, cannot be canceled by the seller because the sale and purchase has been paid in full by the buyer.

In making the notarial deed of vacating the house, besides being preceded by a sale and purchase deed made before the Land Deed Making Officer (PPAT), it can also be preceded by a sale and purchase binding agreement made before a notary

\footnotetext{
${ }^{22}$ Ridwan Khairandy, loc. cit.
} 
The purpose of making a Sale and Purchase Binding Deed is because the buyer may have a plan to resell the object purchased, other than that it may be due to the certificate of Building Use Rights (HGB) which is almost expired, thus waiting for the process of extending the Building Use Rights (HGB), or the rights will be upgraded to become Property Rights (HM).

The Sale and Purchase Binding Deed is usually also accompanied by a Power of Attorney to Sell. The Deed of Authorization to sell is used to complete the transfer of good name to the beneficiary or to another person, if it is sold to another person.

The House Emptying Agreement is usually in addition to completing the Sale and Purchase Agreement, also to complete other agreements such as personal debt agreements, in the deed there is a clause (article) that regulates sanctions if the debtor cannot pay on time. If the debts in question are guaranteed by the house occupied or collateral for the house used for activities, a deed of agreement to vacate the house is made. 23

Before the Deed of Sale and Purchase is made as a the basis for making a Notarial Deed of Employment Agreement, then what needs to be asked of the seller and buyer is: the certificate that will be the object of the sale and purchase, because if the certificate is still under guarantee, the credit must be paid off first by the seller to free the certificate that is bound as collateral. After the certificate is no longer a credit guarantee, the certificate is first checked at the local Land Office, so that it can be seen whether there is a block or there is no dispute. If the certificate has previously been installed with mortgage rights, then a roya must be carried out first, to ensure that the certificate is free from the burden of credit loans, and further inspection must be carried out before the deed of sale and purchase is made. On the other hand, if the certificate was not previously attached with mortgage rights, then before the sale and purchase, the obligation to check the certificate must still be carried out even though there is no roya. ${ }^{24}$

The conditions that must be met and submitted by the seller and the buyer or the parties before the Deed of Sale and Purchase are made are the original certificate, the seller's and the buyer's electronic Identity Card (KTP), the seller's electronic identity card (KTP), and the family card (KTP). KK) of the seller and the buyer, the latest (original) Land and Building Tax Payable Tax Return (SPPT-PBB) and has been paid off if it has not been checked online first whether there are unpaid arrears or not, Taxpayer Identification Number (NPWP) of the seller and buyer if any.

You must ask the seller and the buyer whether the payment has been paid off or not, because buying and selling must be in cash. If it has not been paid off, the Sale and Purchase Deed cannot be made. If it has not been paid off, a deed of sale and purchase agreement is made, the clause of which regulates the stages

\footnotetext{
${ }^{23}$ Interview with Dwi Murti Setyowati, SH, loc. cit.

24 Ibid.
} 
of payment until settlement, after being paid off, it is only made in the sale and purchase.

After the buyer has paid off, the seller must submit the house in an empty state by providing the house key, but if the seller asks for time to vacate the house, then upon the agreement of the seller and buyer an agreement can be made to vacate the house. In the deed of agreement to vacate the house notarized before a Notary, among others, there is a clause that regulates when the seller vacates the house at the latest.

In the agreement to vacate the house, it is necessary to include a clause that the buyer is obliged to provide severance pay to the seller as much as agreed by both parties. Severance pay must be paid by the buyer to the seller after the house is delivered empty by the seller to the buyer. This is intended as compensation that has been agreed between the seller and the buyer, and as a balance between the rights and obligations obtained by both parties in the agreement.

By making a sale and purchase agreement and a notarial house emptying agreement which regulates the terms and contains the theoretical basics of the legal protection mentioned above, it is primarily intended to provide legal protection to the buyer because the buyer cannot immediately occupy the house after the sale and purchase agreement is made. . Furthermore, the basis for making a notarial house emptying agreement, because the principle of buying and selling is cash, namely payment or delivery of money followed by delivery of the goods (objects) being sold.

\subsection{Constraints and Solutions to Realize a Sense of Justice in the Implementation} of Notary House Emptying Agreements in the Sale and Purchase of Land and Buildings

1) Obstacles to Realizing a Sense of Justice Against the Implementation of Notary House Evacuation Agreements in the Sale and Purchase of Land and Buildings

Hans Kelsen in his book General Theory of Law and State, is of the view that law as a social order can be declared fair if it can regulate human actions in a satisfactory way so that they can find happiness in it. ${ }^{25}$

Obstacles in the implementation of the notarial vacancy agreement if the seller or other person who is still occupying the house does not immediately leave or vacate the house in accordance with the agreement. Another obstacle is that the buyer or home owner cannot pay or give severance pay to the seller or other people who occupy the house, even though the seller or other people who occupy the house are ready to leave or vacate the house in accordance with the agreed time.

\footnotetext{
${ }^{25}$ Hans Kelsen, Loc. cit.
} 
Therefore, the things that need to be considered and included in the notarial vacancy agreement are:

a. When can the seller or the person occupying the house leave or vacate the house he is selling and hand over the keys to the house he is selling.

b. How much severance pay is received by the seller when he leaves or vacates the house he sells and submits the keys to the house he sells.

c. How long the seller is given time by the buyer to occupy the house he is selling.

d. When the seller can leave or vacate the house he is selling along with the delivery of the keys to the house being sold.

e. If the specified date turns out to be that the seller or the occupant cannot leave the house he is selling to the buyer, a fine per day is imposed, the amount of which is agreed upon by the parties, namely between the seller and the buyer.

f. The length of time the fine is valid.

g. What if the buyer cannot pay or provide severance pay to the occupants, even though the seller or other occupying persons are ready to leave or vacate the house.

h. Penalties to buyers if they do not pay severance pay.

i. After the expiry of the penalty period, the buyer can ask for help from the authorities/police to vacate the house he bought.

The fine sanction in the notarial house emptying agreement aims to make the agreement effective as desired by the parties, namely the seller and the buyer, to obtain legal certainty. ${ }^{26}$

2) Solutions to Realize a Sense of Justice in the Implementation of Notary House Emptying Agreements in the Sale and Purchase of Land and Buildings

${ }^{26}$ Interview with Dwi Murti Setyowati, SH, loc. cit. 
The seller who still occupies the house that has been sold to the buyer at the time of signing the Deed of Employment Agreement before a Notary, promises to leave or vacate the house he occupies on the agreed date and stated in the notarial agreement to vacate the house.

If at the specified time has not yet been able to leave or vacate the house, then upon agreement the buyer can give an additional time allowance of one week or more according to the agreement, provided that each day is subject to a fine. For a specified time for example one week after one week, the buyer can ask the authorities/police for assistance to forcibly remove the occupants' belongings.

If the house being sold is occupied by another person or the tenant at the time of signing the deed before a notary, the seller and/or other person occupying the house will also sign the notarial deed of agreement to vacate the house together with the buyer. Furthermore, the house sold by the seller is still occupied by the tenant, then the emptying of the house being sold waits until the expiration date of the lease agreement or the seller is given a replacement in the form of money as compensation for the tenant to leave or vacate the house that has been sold, or the tenant is given a replacement for the house that has been sold.

As for the buyer, if the person who occupies the house or the seller is ready to hand over the house and the keys to the buyer but the buyer is unable to provide severance pay as agreed between the seller and the buyer, the buyer is also subject to a daily fine and the seller is still allowed to occupy the house until the buyer is ready to give money. Thus the seller will receive severance pay plus a fine every day. ${ }^{27}$

\section{Closing}

In the sale and purchase agreement of land on which a house is built, which is made before the Land Deed Making Officer (PPAT), if the seller or other person who occupies the house has not been able to leave or vacate the house, it is necessary to make a separate agreement in the form of a notarial agreement to vacate the house. The notarial vacancy agreement cannot be separated and complements each other with a sale and purchase agreement, because the parties or the subject and object are the same between the two agreements. To obtain legal certainty and protection in the vacating of the house, the seller and the buyer or the parties agree to make a notarial deed of agreement to vacate the house before a notary. Legal protection can be divided into preventive legal protection and repressive legal protection. Preventive legal protection is

\footnotetext{
27 Ibid.
} 
provided based on statutory regulations. Legal protection for buyers with good intentions can be found in several articles of legislation, including Article 1491 of the Civil Code. While repressive legal protection is protection given when there has been a violation of the law. The form of protection is in the form of law enforcement which includes the provision of sanctions.

\section{References}

Journals:

[1] Deen, Thaufiq., Ong Argo Victoria \& Sumain. (2018). Public Notary Services In Malaysia. JURNAL AKTA: Vol. 5, No. 4, 1017-1026. Retrieved from http://jurnal.unissula.ac.id/index.php/akta/article/view/4135

[2] Farhati, Dewi \& Akhmad Khisni. (2018). Legal Review Of Implementation Endowments Authority Relating To The Under Hand Agreement Made By Waqif (Case Study In Kua Wonosalam, Demak). JURNAL AKTA: Vol. 5, No. 3.

http://jurnal.unissula.ac.id/index.php/akta/article/view/3256/2392

[3] Rachmawati, Noor., \& Hanim, Lathifah. (2018). Notary Role in The Establishment of Foreign Investment Limited Company Based on The Act No. 25 Of 2007 on Investment in Semarang. JURNAL AKTA: Vol. 5, No. 4, 965-974.

Retrieved

from

http://jurnal.unissula.ac.id/index.php/akta/article/view/3939

[4] Sukarmi \& Ong Argo Victoria. (2018). Cash Waqf in Sustaining of Indonesian Society "In Legal \& Economic Perspective". AL-ITQAN: Journal of Islamic Sciences: IIUM Malaysia. https://journals.iium.edu.my/alitqan/index.php/al-itqan/article/view/43

[5] Widyawati, \& Handoko, Widhi. (2018). The Notary Role / PPAT in Improving Legal Awareness Society to Perform Registration Rights to Land Based on Government Regulation No. 24 of 1997 on Land Registration. JURNAL AKTA: Vol. 5, No. 4, 975-980. Retrieved from http://jurnal.unissula.ac.id/index.php/akta/article/view/4127

Books:

[1] Abdulkadir Muhammad, Hukum \& Penelitian Hukum, (Bandung : Citra Aditya Bakti, Bandung, 2004)

[2] Ahmadi Miru, Hukum Kontrak Perancangan Kontrak, (Jakarta: Raja Grafindo Persada, 2007)

[3] Gunawan Widjaja and Kartini Muljadi, Jual Beli, (Jakarta: PT Raja Grafindo Persada, 2003)

[4] Kartini Muljadi \& Gunawan Widjaja, Perikatan Yang Lahir dari Perjanjian, (Jakarta: Raja Grafindo Persada, 2008 
[5] Philipus M. Hadjon, 2011. "General Theory of Law and State", diterjemahkan oleh Rasisul Muttaqien, Bandung, Nusa Media

[6] Ridwan Khairandy, Itikad Baik dalam Kebebasan Berkontrak, (Jakarta: Fakultas Hukum Universitas Indonesia, 2003)

[7] Ridwan Khairandy, Kebebasan Berkontrak \& Pacta Sunt Servanda Versus Iktikad Baik:Sikap Yang Harus Diambil Pengadilan, FH UII Press

[8] Subekti, Hukum Perjanjian, (Jakarta: Intermasa, 2008)

[9] Widyarini, Indriasti Wardani et al, 2018, Hukum Pertanahan, Semarang, Faculty of Law, University of 17 August 1945 (UNTAG) Semarang.

[10] Yunirman Rijan and Ira Koesoemawati, Cara Mudah Membuat Surat Perjanjian/Kontrak \& Surat Penting Lainnya, (Jakarta: Raih Asa sukses, 2009)

Regulations:

[1] Act No. 2 of 2014 concerning Amendments to Law

[2] Act No. 20 of 2000 concerning BPHTB.

[3] Act No. 30 of 2004 concerning the Position of a Notary.

[4] Burgerlijk Wetboek voor Indonesiadone (BW).

[5] Constitution of the Republic of Indonesia 1945.

[6] Government Regulation Number 24 of 1997 concerning Land Registration.

[7] Government Regulation of the Republic of Indonesia Number 37 of 1998 concerning Regulations on the Position of Land Deed Maker Officials.

Interview:

Interview with Dwi Murti Setyowati, SH, Notary and Official of Land Deed Maker in Pemalang Regency in Randudongkal. 